\title{
STRATEGIES OF INTRODUCTION
ENVIRONMENTAL PROTECTION ISSUES TO
THE SCIENCE EDUCATION IN POLAND
}

\author{
Małgorzata Krzeczkowska, Ewa Odrowąż, \\ Elżbieta Szostak \\ Faculty of Chemistry, Jagiellonian University, Poland
}

\begin{abstract}
Since 1999 a study subject called 'Elements of Science' has existed in Polish primary schools. Elements of the science covers issues from biology, geography, physics and chemistry. There is no separate university course of studies in Poland that would prepare teachers to teach this subject. Natural science is taught by biology, chemistry, geography, and physics teachers, who obtain additional accreditation in order to teach this subject (GrodzinskaJurczak, 2000). Students of the Jagiellonian University's chemistry department can also obtain these credentials. In order to do so, they must participate in the Methodology of Teaching of Science course. One of the elements of this course is environmental education. The first aim of this study was to determine to what extent the students at various levels of the educational system are familiar with ecological problems. The second aim was to develop a format for lessons that can be used by teachers to introduce ecological issues in the classroom or through extra-curricular activities.
\end{abstract}

Key words: environmental protection, science, primary school, reduce-reuse-recycle.

\section{Introduction}

Interest in problems of environmental protection has grown over recent years in Poland (Grodzinska-Jurczak, 2000; Gajuś-Lankamer, 2004; Kobierska, Tarabuła-Fiertak \& Grodzinska-Jurczak, 2010) and in many other countries (Conde \& Sanchez, 2010; Srbinovski, Erdoganb \& Ismaili, 2010; Yavetz, Pe'er \& Goldman, 2009, Flogaitis, Daskolia \& Agelidou, 2005). In the Polish education system, no separate subject is foreseen in which pupils would be introduced to these problems (Grodzinska-Jurczak, 2000). Teachers include environmental issues in other subjects such as elements of science at the primary school level, or biology, chemistry and geography at the lower or upper secondary school level. Environmental protection is offered as a separated subject only at university level (Tarabuła-Fiertak et al., 2004). For this reason, university students preparing for teaching elements of science, should make preparations for introducing those issues in primary school. Unfortunately, in Poland students can not specialize in methodology of teaching elements of science. Science didactics is only extraordinary course for teachers of others general science subjects which gives accreditation for teaching elements of science. Chemistry students at the Jagiellonian University can also obtain these credentials. In order to do so, they must participate in the Methodology of Teaching of Science course. The exercises included in this course introduce various methods and ways of working with university students, which can be useful in the teaching of ecological issues. Newly proposed methods are examined and approved based on their usefulness in the classroom. 
The aim of the study was to develop form of lessons that can be used by teachers to introduce ecological issues. Efficient teaching at the primary level must be conducted in an engaging and various fashion (Walberg, 1976; Devetak et al., 2009). The primary school pupils prefer to learn by playing (Gulińska, 2010; Pedroso \& Amorim, 2009). The making interesting games and the adaptation of them to the needs, abilities, and interests of the pupils mean that these mental tasks are better able to stimulate pupil involvement than other teaching methods, and solving puzzles can give pleasure and satisfaction. One form of educational game could be the preparation by pupils of a 'mini scientific session' on a given theme under the direction of the teacher. These are classes of a workshop type, using the ingenuity and creativity of the teacher and pupils, including multimedia presentations, skits, educational games, movies, puzzles, and so on.

\section{Methodology of Research}

In order to determine the usefulness of this method of teaching, a survey of university students who had prepared and conducted a 'mini scientific session' as a part of the course was conducted. The theme of the session was the $3 \mathrm{x}$ R: reduce, reuse and recycle.

The content produced in exercises of this type should mainly concern the issues with which the pupils have the most significant misunderstandings. For this reason a questionnaire survey was taken of primary school pupils which was to indicate which subjects were already well known to them and which should be focused on in classes. Additionally, the same survey was taken in lower secondary and upper secondary schools to determine if these issues had already been mastered by the upper levels of education.

\section{Research Tools}

The survey for pupils concerning various aspect of ecology contained 10 open questions requiring in-depth reflection on the subject, and sometimes impulsive answer based on first association; 1 semi-open questions where one suggested answer could be selected and justified or own answer entered, and 2 closed questions as well as the respondent personal data.

The survey for students (when university seminar finished) concerning various aspect of school science activities contained 10 open questions and 2 closed questions.

\section{Tool Verification}

It is obvious that the survey questions have to be concrete; language used in the survey must be adjusted to age. Pilot research was conducted in December 2009 in order to assure that the developed survey meets these requirements. This research included test filling of the questionnaire and subsequent interviews with the respondents. It allowed to determine approximate time of the survey completion.

Group of Respondents

Characteristic of respondents is presented in Table 1. 
Table 1. Characteristic of respondents.

\begin{tabular}{|l|c|c|c|c|}
\hline & $\begin{array}{c}\text { Primary } \\
\text { school }\end{array}$ & $\begin{array}{c}\text { Lower second- } \\
\text { ary school }\end{array}$ & $\begin{array}{c}\text { Upper second- } \\
\text { ary school }\end{array}$ & $\begin{array}{c}\text { University lev- } \\
\text { el }\end{array}$ \\
\cline { 2 - 5 } & $\begin{array}{c}10-12 \text { years old } \\
\text { girls and boys }\end{array}$ & $\begin{array}{c}13-15 \text { years old } \\
\text { girls and boys }\end{array}$ & $\begin{array}{c}16-18 \text { years old } \\
\text { girls and boys }\end{array}$ & $\begin{array}{c}24-25 \text { years old } \\
\text { girls and boys }\end{array}$ \\
\hline $\begin{array}{l}\text { the number of } \\
\text { respondents }\end{array}$ & 107 & 97 & 113 & 18 \\
\hline
\end{tabular}

\section{Collection of Data}

Surveying was conducted in the January and the February of 2010. A total of 335 surveys were collected.

The results and discussion presented below have been divided into two parts:

a) part I - research conducted among pupils,

b) part II - scenario of the 'mini session' and results of the questionnaire survey conducted among students.

\section{Part I: The Questionnaire Survey Among Pupils}

\section{Results of Research}

Questions from the questionnaire and achieved results are presented below in the subparts and tables.

Q.1. Write down your first associations with the expression: $3 \times \mathrm{R}$ : reduce, reuse, recycle (Table 2).

Table 2. Pupils' associations.

\begin{tabular}{|l|c|c|c|}
\hline \multirow{2}{*}{ Associations } & \multicolumn{3}{|c|}{ \% of pupils who indicated the given associations } \\
\cline { 2 - 4 } & Primary school & $\begin{array}{c}\text { Lower secondary } \\
\text { school }\end{array}$ & $\begin{array}{c}\text { Upper } \\
\text { secondary school }\end{array}$ \\
\hline Environment & 19 & 52 & 43 \\
\hline Recycling & 36 & 22 & 7 \\
\hline $\begin{array}{l}\text { Translation of expression } \\
\text { into the Polish language }\end{array}$ & 8 & 20 & 38 \\
\hline No answer & 37 & 6 & 13 \\
\hline
\end{tabular}

the pupils frequently gave more than one answer

Q.2. Forms of environmental awareness are expressed in practice by different activities undertaken by different people. Give examples of these activities (Table 3). 
Table 3. Activities most frequently given as responses.

\begin{tabular}{|c|c|c|c|}
\hline \multirow[t]{2}{*}{ Activity } & \multicolumn{3}{|c|}{ \% of pupils who indicated the given activity } \\
\hline & $\begin{array}{c}\text { Primary } \\
\text { school }\end{array}$ & $\begin{array}{c}\text { Lower secondary } \\
\text { school }\end{array}$ & $\begin{array}{c}\text { Upper secondary } \\
\text { school }\end{array}$ \\
\hline Separation of wastes & 52 & 30 & 37 \\
\hline $\begin{array}{l}\text { Ecological and awareness } \\
\text { promotion actions }\end{array}$ & 21 & 24 & 29 \\
\hline $\begin{array}{l}\text { Conservation of water and } \\
\text { electricity }\end{array}$ & 12 & 9 & 10 \\
\hline Ecological packaging & 5 & 8 & 6 \\
\hline
\end{tabular}

Q.3. Which of these activities are performed in your house?

$62 \%$ of all respondents indicated segregation of wastes as an activity performed in their homes. $26 \%$ indicated conservation of water and electricity, and $13 \%$ used ecologicallyfriendly packaging, but as many as $28 \%$ of those surveyed claimed that no ecological activities were undertaken in their homes.

Segregation of wastes requires disposing of them in the appropriate containers, so the following questions were designed to check knowledge of the proper disposal of specific waste items.

Q.4. Can the following items be disposed of in the bin for (Table 4):

paper: cardboard boxes, used wallpaper, envelopes with cellophane window for the address.

metal: aluminium cans, beverages cans, paint cans, used batteries.

plastic: plastic lids, plastic fruit baskets, toys, small appliances.

glass: glass cosmetic jars, bottles and jars for food, light bulbs, mirrors.

Table 4. Percentage of pupils who gave all the correct responses.

\begin{tabular}{|l|c|c|c|}
\hline Bin for: & \multicolumn{3}{|c|}{ \% of pupils who correctly ticked all the indications } \\
\hline & Primary school & $\begin{array}{c}\text { Lower secondary } \\
\text { school }\end{array}$ & $\begin{array}{c}\text { Upper secondary } \\
\text { school }\end{array}$ \\
\hline Paper & 36 & 44 & 44 \\
\hline Metal & 22 & 21 & 31 \\
\hline Plastic & 57 & 52 & 42 \\
\hline Glass & 29 & 50 & 35 \\
\hline
\end{tabular}


Table 5. Percentage of pupils who incorrectly indicated that a given product should be disposed of in a given bin:

\begin{tabular}{|l|c|c|c|}
\hline \multirow{2}{*}{ Product } & \multicolumn{3}{|c|}{ \% of pupils who incorrectly qualified given product } \\
\cline { 2 - 4 } & Primary school & $\begin{array}{c}\text { Lower secondary } \\
\text { school }\end{array}$ & $\begin{array}{c}\text { Upper secondary } \\
\text { school }\end{array}$ \\
\hline $\begin{array}{l}\text { Envelopes with cellophane } \\
\text { window for the address }\end{array}$ & 29 & 27 & 38 \\
\hline Used wallpaper & 34 & 28 & 25 \\
\hline Paint cans & 74 & 78 & 73 \\
\hline Used batteries & 7 & 0 & 2 \\
\hline Toys & 38 & 47 & 50 \\
\hline Small appliances & 9 & 4 & 15 \\
\hline Light bulbs & 24 & 15 & 57 \\
\hline Mirrors & 53 & 47 & \\
\hline
\end{tabular}

Protection of the environment does not only mean the segregation of wastes, but also appropriate conservation of materials made through industrial processes. The following questions tested the ability to do this properly.

Q.5. Below is a list of products sold in traditional packaging. Please check the type of packaging that you believe is most frequently purchased and the one that should be chosen for ecological reasons (Table 6).

Table 6. Percentage of pupils who selected the given response.

\begin{tabular}{|c|c|c|c|c|c|c|c|}
\hline \multirow[t]{2}{*}{ Product } & \multirow[t]{2}{*}{ Packaging } & \multicolumn{3}{|c|}{ Bought $[\%]$} & \multicolumn{3}{|c|}{ Should be bought $[\%]$} \\
\hline & & $\begin{array}{l}\text { Primary } \\
\text { school }\end{array}$ & $\begin{array}{l}\text { Lower } \\
\text { secondary } \\
\text { school }\end{array}$ & $\begin{array}{l}\text { Upper } \\
\text { secondary } \\
\text { school }\end{array}$ & $\begin{array}{l}\text { Primary } \\
\text { school }\end{array}$ & $\begin{array}{l}\text { Lower } \\
\text { secondary } \\
\text { school }\end{array}$ & $\begin{array}{l}\text { Upper } \\
\text { secondary } \\
\text { school }\end{array}$ \\
\hline Milk & $\begin{array}{l}\text { Cardboard } \\
\text { carton } \\
\text { Bag } \\
\text { Glass bottle } \\
\text { Plastic } \\
\text { bottle }\end{array}$ & $\begin{array}{c}78 \\
\\
3 \\
5 \\
21\end{array}$ & $\begin{array}{c}77 \\
\\
4 \\
6 \\
13\end{array}$ & $\begin{array}{l}50 \\
1 \\
3 \\
6\end{array}$ & $\begin{array}{c}36 \\
\\
7 \\
48 \\
9\end{array}$ & $\begin{array}{c}38 \\
\\
1 \\
60 \\
5\end{array}$ & $\begin{array}{c}19 \\
\\
3 \\
66 \\
3\end{array}$ \\
\hline Toothpaste & $\begin{array}{l}\text { Tube } \\
\text { Tube in } \\
\text { cardboard } \\
\text { box } \\
\text { Box } \\
\text { wrapped in } \\
\text { plastic film }\end{array}$ & $\begin{array}{l}57 \\
36 \\
10\end{array}$ & $\begin{array}{l}43 \\
44 \\
\\
15\end{array}$ & $\begin{array}{l}63 \\
44 \\
16\end{array}$ & $\begin{array}{l}69 \\
12 \\
10\end{array}$ & $\begin{array}{l}60 \\
33 \\
4\end{array}$ & $\begin{array}{l}81 \\
19 \\
0\end{array}$ \\
\hline Beverages & $\begin{array}{l}\text { Plastic } \\
\text { bottle } \\
\text { Glass bottle } \\
\text { Aluminium } \\
\text { can }\end{array}$ & $\begin{array}{l}83 \\
14 \\
10\end{array}$ & $\begin{array}{c}85 \\
6 \\
10\end{array}$ & $\begin{array}{c}84 \\
6 \\
12\end{array}$ & $\begin{array}{l}22 \\
60 \\
14\end{array}$ & $\begin{array}{l}12 \\
73 \\
10\end{array}$ & $\begin{array}{c}3 \\
87 \\
8\end{array}$ \\
\hline
\end{tabular}

Ecologically-friendly products are marked with the appropriate symbols, known as eco-labels (Krzeczkowska et al., 2009). The following questions tested knowledge of selected eco-labels.

Q.6. From among the symbols given below, underline the eco-labels (Table 7). 
Table 7. Percentage of pupils identifying the given symbol as an eco-label.

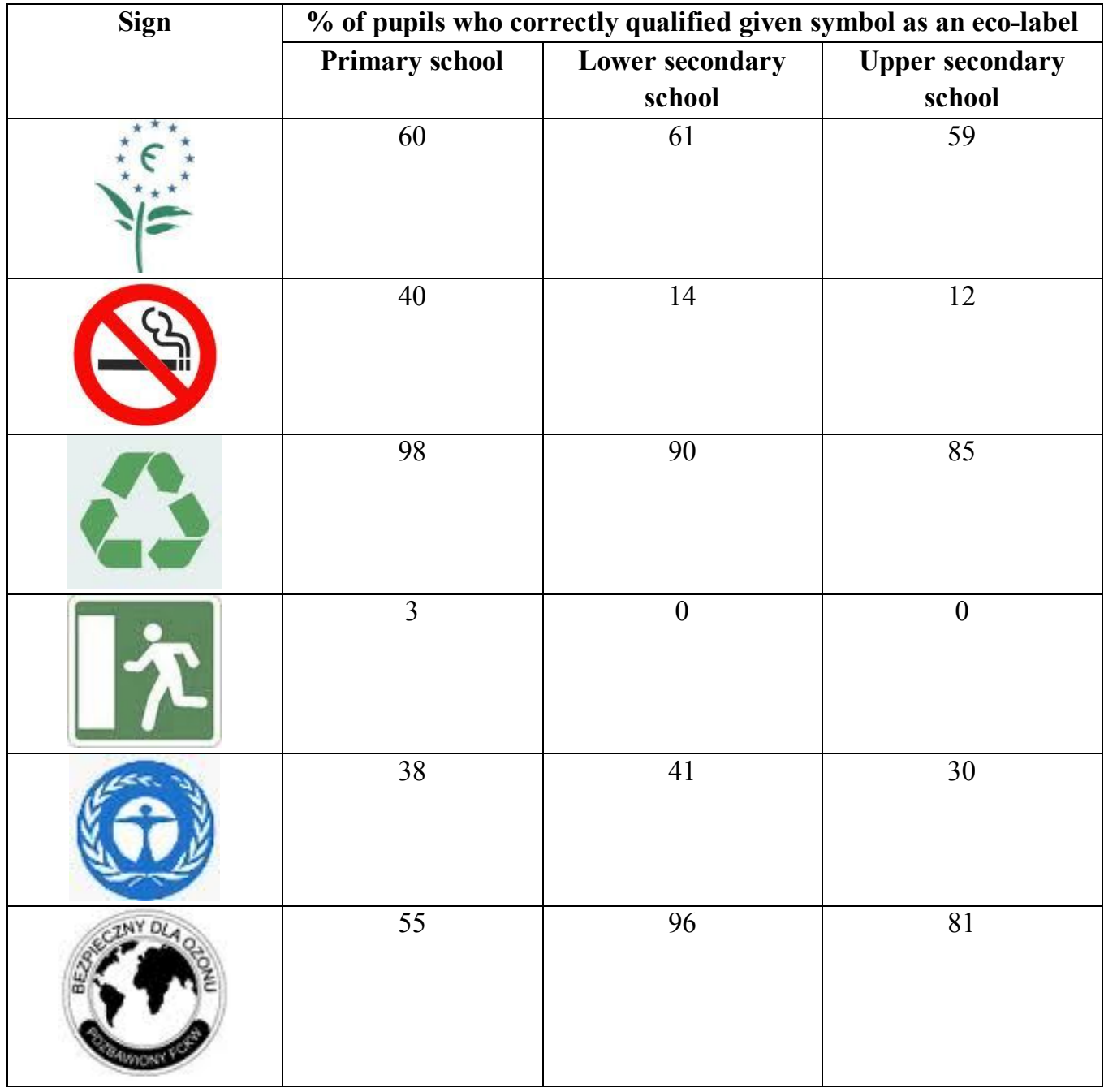

Finally, the respondents were asked their opinions on the following topics

$>$ Do you think that the various, Poland-wide initiatives such as 'Clean Up the World' are appropriate? Give your reasons.

$>$ Do you think that environmental problems are being identified and solved appropriately?

According to the studies, $75 \%$ of those questioned believed that ecological actions makes sense, because they increase environmental awareness in society. At the same time, $74 \%$ believed that problems of environmental protection are not perceived by local governments and organizations or resolved to an appropriate degree, especially due to:

$>$ the lack of appropriate legal regulations

$>$ the lack of an appropriate number of waste containers

$>$ small number of informational campaigns and educational activities. 


\section{Discussion}

Responses to Q.1 question indicate that the majority of respondents associate the " 3 x R" concepts with environmental problems. It was also noted that with increasing age, an increasing number of pupils provided simple translations of these terms into the Polish language (in the survey, words reduce, reuse, recycle were given in English).

Results of Q.2 and Q.3 have showed that a relatively high level of environmental awareness is not necessarily associated with real-life day-to-day actions.

The results obtained are consistent with a nationwide survey on the topic of 'The ABCs of wastes segregation' conducted by the Minister of the Environment, according to which 52.7\% of Poles stated that they segregate waste in their homes (Dec, 2009).

From the results obtained in Q.4 the conclusion can be drawn that the while the respondents indicate that they separate wastes in their homes, they are not completely aware of which items should be disposed of in which bins (Table 5).

The pupils had the greatest difficulty with empty paint containers, mirrors, and with toys.

A small percentage of the youngest children said they would dispose of batteries in the metal bins (Table 5). This confirms the efficacy and effectiveness of the ongoing nation-wide battery collection campaign.

The responses given in question Q.5 (Table 6) indicate that young people know which types of packaging should be purchased in order to reduce the amount of waste produced. The results also show that pupils try to choose the best possible products, but that the selection of products available on the market limits their choices.

As show results of question Q.6 (Table 7) the most recognizable are the recycling symbol, the marking for ozone-friendly products and Eco-Flower. The respondents knew that the 'emergency exit' symbol is not an eco-label, while a majority of women associated the 'no smoking' symbol with ecology, although this number declined with increasing level of education.

\section{Part II: Scenario of the mini session and results of the questionnaire survey conducted among students}

\section{A. Scenario of the mini session}

The students developing the 'mini scientific session' entitled $3 \times R$ were divided into three groups. One of the three topics reduce, reuse and recycle was assigned to each group. In preparing their session on the given subject they were to take into account the results of the survey of the pupils. Those results indicated that particular attention should be given to the problem of segregation of wastes, and also to informing the pupils that segregation is not the only environmentally positive activity that they can take.

Pupils should also be made aware that every individual has a responsibility for the condition of our natural environment, and that their actions can have a positive impact on the state of the environment and the place where they live.

Each group prepared a lesson plan for pupils in primary school and carried out demonstrations in which the remaining university students were the participants. A wide variety of activities was proposed for these classes: multimedia presentations, educational games, fashion shows employing reused materials and films made by the university students.

Sample tasks submitted by the university students are given below: 


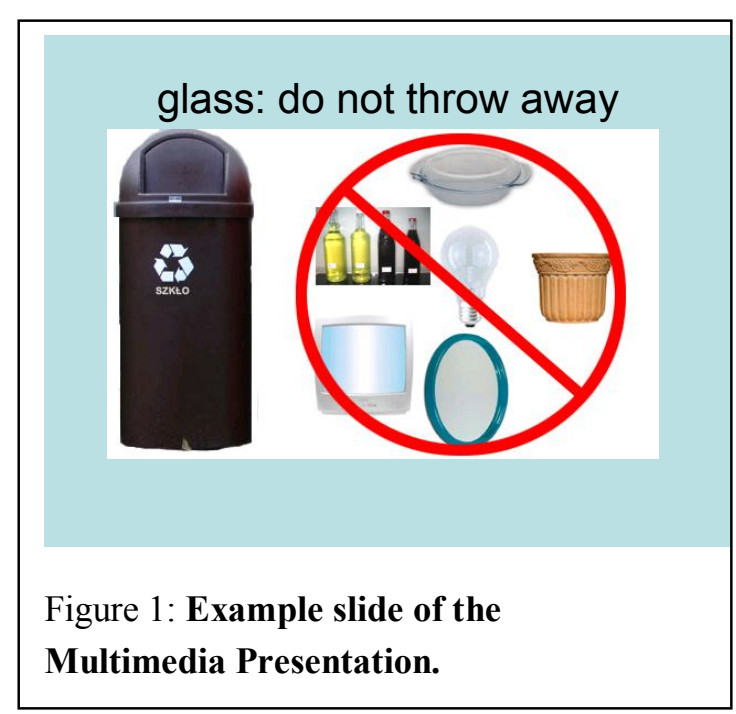

bles
1. Let's separate our rubbish.

The teacher sets up cardboard boxes painted in the appropriate colours, respective to the waste bins, along with a 'collection' of various kinds of rubbish: paper, candy wrappers, window envelopes, batteries, plastic and glass bottles, juice cartons, beverage cans, etc.

The pupils' task is to separate the wastes properly.

The summary and checking of the task is given as a multimedia presentation.

2. We segregate our rubbish, then what happens?

Pupils receive work sheets, on which they write what sort of products can be reclaimed from examples of recycla-

Table 8. Work sheet.

\begin{tabular}{|l|c|l|}
\hline \multicolumn{1}{|c|}{ Example of recyclable material } & $\begin{array}{l}\text { Secondary raw } \\
\text { material }\end{array}$ & $\begin{array}{l}\text { New product } \\
\text { (examples of pupils answers) }\end{array}$ \\
\hline $\begin{array}{l}\text { Paper packaging, used cardboard } \\
\text { boxes, old newspapers, etc. }\end{array}$ & wastepaper & $\begin{array}{l}\text { New paper, such as: toilet paper, } \\
\text { cardboard, newspapers, } \\
\text { books, } \text { notebooks }\end{array}$ \\
\hline $\begin{array}{l}\text { Glass bottles, jars, damaged glass } \\
\text { items }\end{array}$ & glass & $\begin{array}{l}\text { reused bottles and jars, new glass } \\
\text { goods, road hardening additives }\end{array}$ \\
\hline $\begin{array}{l}\text { Sheet metal, springs, old metal } \\
\text { items, aluminium cans }\end{array}$ & scrap metal & $\begin{array}{l}\text { new metal goods, pots and pans, } \\
\text { car bodies, } \text { etc. } \\
\text { sheet metal }\end{array}$ \\
\hline Potato peels, fruit rinds, etc. & food waste & compost - natural fertiliser \\
\hline Plastic bottle & plastic packaging & new packaging and plastic goods \\
\hline
\end{tabular}

3. How do we reuse items at home?

In order to demonstrate to the pupils the possibility of limiting the amount of waste produced by reusing items, a set of creative activities were proposed, in which:

$>$ they painted glass preserves jars which could then be used as, for example, containers for seasonings or as vases

$>$ they made paper mache, from which they formed various types of decorations

$>$ by covering plastic beverage bottles with paper mache, making vases

$>$ they made Christmas tree decorations from colourful newspapers

$>$ they decorated egg cartons, turning them into purses and treasure-boxes.

4. To encourage the pupils to think about the ways that each of us in our everyday lives, and in the decisions we make while shopping can shape today's world through the selection of ecologically-friendly products, which are marked with eco-labels. After viewing a multimedia presentation on eco-labels, the participants, divided into groups of three, receive envelopes as in a memory game. Each envelope is numbered respectively 1, 2 and 
3. In the first envelope are drawings of the eco-labels, in the second the names of the ecolabels, and in the third descriptions of them in writing. The object of the teams is to combine the three elements as quickly as possible.

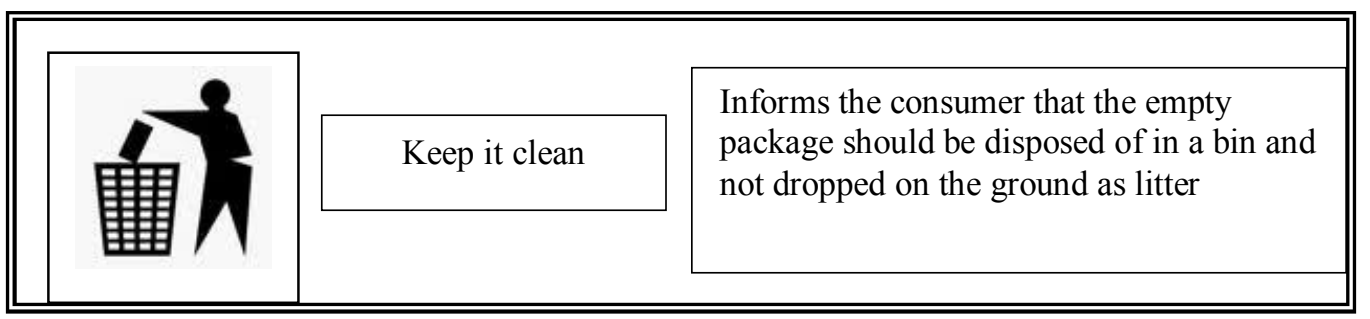

Figure 2: Example of a correct answer.

\section{B. Results of the questionnaire survey conducted among students}

The results of the survey conducted of the university students after the workshop activities indicated that (from chosen questions):

Q.1. Whether this type of course (e.g. mini session) allows you to prepare for the teaching profession?

$59 \%$ of the university students felt that the creation of and participation in these sorts of activities play a vital role in preparation for a teaching career, while $17 \%$ stated that their usefulness was low, and $24 \%$ were unable to evaluate them.

Q.2. Which key skills may be developed by participating in this type of activities?

The activities provided strong development of key skills such as:

$>$ Development university students teamwork skills $-72 \%$ of respondents

$>$ Development university students discussion skills $-72 \%$ of respondents

$>$ Familiarisation with the topic of the session $-89 \%$ of respondents

$>$ Familiarisation with methods of working actively with children $-56 \%$ of respondents

Q.3. Write three benefits for teachers from the conduct of such activities? Write three benefits for pupils from the participation in such activities?

The benefits of the conduct of the activities for both the teacher and the pupils are given in table 9 .

Table 9. Benefits of activities.

\begin{tabular}{|l|l|}
\hline \multicolumn{1}{|c|}{ For the teacher } & \multicolumn{1}{c|}{ For the pupil } \\
\hline $\begin{array}{l}\text { Involvement of the entire class } \\
\text { Interesting form of presentation of in- }\end{array}$ & Development of individual passion \\
formation & Opportunity to express own creativity \\
Different way of conducting class & Exercise teamwork skills \\
Inter-subject correlation & Expansion of awareness in a fun way \\
Stimulation of own creativity & Practice of self-expression and discussion skills \\
Learning about the pupils' predisposi- & Classroom team-building \\
tions & Practice public speaking skills \\
Self-teaching & Practice of information-seeking skills and selec- \\
Awakening among pupils of ecological & tion of appropriate facts \\
awareness & \\
\hline
\end{tabular}




\section{Discussion}

According to students opinion, such kind of school activities (e.g. mini session) play the important role in their proper preparation for future work as a teacher. Participation in this activity gives the opportunity to develop different key skill, especially team work and discussion skills. The use of the projects in class was also associated with difficulties, among which the university students counted time and labour intensiveness.

\section{General Conclusion}

The results of these surveys indicate that despite the fact that the problems of environmental protection are known to the pupils, ecological education is still necessary. Ecological education should be introduced from the youngest age and continued at every level of education. In order for pupils to be convinced of the need to protect nature, they must come into contact with nature. The process cannot, however, end with dry conveyance of knowledge. Emotions are important in work with children. Children should learn through play. In this way they can feel connected to nature, developing emotional bonds. Older children will need other types of work, but they should always lead to the understanding that nature is useful to people and that it must be respected.

The proposed activities entitled the 'mini scientific session', due to the many benefits to both the teacher and the pupils, would be worthwhile to disseminate among teachers of nature subjects. They can be used at any level of education, varying only in the type of task and the amount of material introduced.

The topics of the activities can depend on the level of education, local environmental problems, the pupils' interests and the curricular requirements. The issues addressed must be prepared on the basis of the preliminary survey results for the given topic, conducted among the pupils before the activities.

Because of their labour and time intensiveness of, a solution may be to base the lesson plan on activities provided in supplementary materials. The teachers could modify and use them according to their own needs.

Plans for activities on the topics of global warming, the ozone hole, water protection, and eco-labels have already been prepared by students of the Chemistry Department of the Jagiellonian.

While the above methodologies were researched in Poland, they may be used with success by teachers in other countries, as the problem of environmental protection is recognised around the world.

\section{References}

Conde, M., \& Sánchez, J.S. (2010) The school curriculum and environmental education: A school environmental audit experience. International Journal of Environmental \& Science Education, 5 (4), 477-494.

Dec, Ł. National Waste Data Report. Polish Ministry of the Environment, Department of Waste Management, 2009.

Devetak, I. et al. (2009). Pre-Service primary teachers' self-determinated behaviour for science learning. European Science Education Research Association, 31.08-4.09, 78.

Flogaitis, E., Daskolia, M. \& Agelidou, E. (2005). Kindergarten Teachers' Conceptions of Environmental Education. Early Childhood Education Journal, 33 (3) 125-136.

Gajuś-Lankamer, E. (2004). Environmental Education at Polish Gymnasiums. International Research in Geographical and Environmental Education, 13 (3) 269-276. 
Gulińska, H. (2010). Modern computer games as elements of teaching chemistry in Polish junior high schools. Journal of Science Education, 11 (1) 4-7.

Grudzinska-Jurczak, M. (2000). Ecological Education in the Polish Educational System. Environmental Science \& Pollution Research, 7 (4) 235-238.

Kobierska, H., Tarabuła-Fiertak, M. \& Grodzinska-Jurczak, M. (2010). Attitudes to environmental education in Poland. Journal of Biological Education, 42 (1) 12-18.

Krzeczkowska, M. et al. (2009). Eco-signs - What we know, about it? Outline of school meeting, $19^{\text {th }}$ International Conference on Chemistry Education, Proceedings (pp 475485). Hradec Kralove, Gaudeamus.

Pedroso, C. \& Amorim, M. (2009). Studies on the use of games in education science: state of the art and perspectives. Journal of Science Education, 10, 153 Proceedings.

Srbinovski, M., Erdoganb, M. \& Ismaili, M. (2010). Environmental literacy in the science education curriculum in Macedonia and Turkey. Procedia Social and Behavioral Science, 2, 4528-4532.

Tarabuła-Fiertak, M. et al. (2004). Environmental Teaching in Higher Education. International Research in Geographical and Environmental Education, 13 (3) 284-290.

Walberg, H. J. (1976). Psychology of learning environments: Behavioral, Structural, or perceptual? Review of Research in Education, 4 (1), 142-178.

Yavetz, B., Pe'er, S. \& Goldman, D. (2009). How do pre-service teachers in Israel perceive the concept environment. European Science Education Research Association, 31.08$4.09,248$.

Received 22 August 2011; accepted 25 October 2011

\begin{tabular}{|l|}
\hline \\
Malgorzata Krzeczkowska \\
Dr., Faculty of Chemistry, Jagiellonian University, ul. Ingardena 3, 30-060 Krakow, Poland. \\
E-mail: krzeczko@.chemia.uj.edu.pl \\
Website: http://zmnch.pl/index.php?option=com content\&view=article\&id=41\&Itemid=37 \\
\hline Ewa Odrowąż \\
Dr., Faculty of Chemistry, Jagiellonian University, ul. Ingardena 3, 30-060 Krakow, Poland. \\
E-mail: odrowaz@.chemia.uj.edu.pl \\
Website: http://zmnch.pl/index.php?option=com_content\&view=article\&id=42\&Itemid=38 \\
\hline Elżbieta Szostak \\
Dr., Faculty of Chemistry, Jagiellonian University, ul. Ingardena 3, 30-060 Krakow, Poland. \\
E-mail: szostak@.chemia.uj.edu.pl \\
Website: http://www.uj.edu.pl/en GB/
\end{tabular}

